\title{
Aspects of iridium extraction from chloride solutions
}

\author{
G. V. Petrov, Professor ${ }^{1}$, e-mail: petroffg@yandex.ru \\ S. B. Fokina, Associate Professor ${ }^{1}$, e-mail: fokina sb@mail.ru \\ T. Yu. Nikitina, Post-Graduate Student ${ }^{1}$, e-mail: nikatatka@yandex.ru
}

${ }^{1}$ Saint-Petersburg Mining University, Saint Petersburg, Russia.

\begin{abstract}
Hydrometallurgical processes for nickel converter matte refining are characterized by the distribution of platinum group metals between the liquid and solid phases. Chlorine refining technology for converter matte consists of oxidation leaching in chloride media and subsequent extraction of nickel from hydrochloric acid solutions. However, during the leaching stage, along with nickel, the transition of platinum group metals in the form of chloride complexes into the solution is possible. The kinetic inertness of iridium complexes makes it difficult to extract iridium from multicomponent solutions. This work includes study of iridium extraction from chloride solutions by reduction methods. The regularities of iridium extraction by cementation method using different metals as cementing agents were revealed, the effect of sulfur-containing precipitators addition is shown.
\end{abstract}

Key words: Iridium, chloride solutions, iridium chloride complexes, reduction processes.

DOI: $10.17580 / \mathrm{nfm} .2021 .01 .02$

\section{Introduction}

$\mathrm{T}$ The most common practice for sulfide coppernickel ores processing is smelting of nickel flotation concentrate to produce matte [1-5]. The matte produced is then converted to converter matte, further refined to produce the saleable nickel, cobalt, and platinum metals [6-7].

A study of global experience in high-purity nickel production shows that hydrometallurgical converter matte refining methods are widespread and prevailing [8-9]. In particular, four international companies use the chlorine extraction and refining technology: the Nikkelverk plant (Glenkore), the Niihama plant (Sumitomo Metal Mining, Japan), the Sandouville plant (Eramet, France), and the Kristiansand plant (Xstrata, Canada). The main operation in the process is oxidation leaching in chloride media with the conversion of nickel to the hydrochloric acid solution. Platinum metals, along with nickel, can also be converted into solution [10-11].

Kola MMC JSC (a subsidiary of MMC Norilsk Nickel PJSC), Russia's only nickel refining facility and the main Russian producer of platinum metals, is currently transitioning to the chlorine leaching technology of nickel oxide produced from flotation nickel concentrate of copper-nickel converter matte with further nickel extraction from hydrochloric acid solutions using electrowinning. It should be noted that historically, Norilsk Nickel refined nickel converter matte using a combined technology - pyrometallurgical extraction of nickel anodes and electrolysis in sulfate media with the concentration of platinum metals in electrolytic slimes.
Accordingly, nickel electrolytic slimes were the basic concentrating agent of platinum metals in the conventional technology used in Russia for sulfide coppernickel ore processing [12-14].

The existing and implemented technologies of converter matte refining in chlorine media differ significantly in terms of conditions of converter matte dissolution and composition of leaching products [10-11]. However, platinum metals in the form of complex chlorides may present in product solutions. In this connection, the problem of extraction of platinum group metals from multicomponent chloride solutions, especially iridium due to its kinetic inertness, is of particular interest [15]. The formation of kinetically inert complexes by iridium makes it difficult to separate iridium from solutions of different compositions and to produce rich iridium concentrates. Iridium reduction processes are promising due to the simplicity of the process and, consequently, process equipment applied [16-19].

\section{Methodology}

Experiments in the extraction of iridium (III) were performed using synthetic chloride solution prepared by the method of sintering with barium peroxide from pure iridium powder [15].

The solutions under study contained iridium of $1.87 \cdot 10^{-3} \mathrm{~mol} / \mathrm{L}(360 \mathrm{mg} / \mathrm{L})$ and optional concentration of hydrochloric acid $(0.19$ to $1.65 \mathrm{~mol} / \mathrm{L})$. Fine powders of zinc and iron were used for iridium extraction, and were introduced at a constant temperature of $80^{\circ} \mathrm{C}$. The test duration was $60 \mathrm{~min}$. Cementing agent consumption 
was varied within the range of 3 to $21 \cdot 10^{-3} \mathrm{~g}$-eq/L. Hydrochloric acid was added to maintain the constant acidity of the medium. Consumption of sodium sulfide, sodium sulfite, and sodium dithionite $\mathrm{Na}_{2} \mathrm{~S}_{2} \mathrm{O}_{4}$ was $12 \cdot 10^{-3} \mathrm{~g}$-eq/L. Consumption of sodium thiosulfate varied from $12 \cdot 10^{-3}$ to $0.5 \mathrm{~g}-\mathrm{eq} / \mathrm{L}$.

Quantitative distribution of iridium (III) and (IV) forms in the synthetic solution were specified using a LEKI SS 1207 spectrophotometer in UV-visible spectra. All testing solutions contained $1.87 \cdot 10^{-3} \mathrm{~mol} / \mathrm{L}$ iridium and $1 \mathrm{~mol} / \mathrm{L}$ hydrochloric acid. The reference solution was $1 \mathrm{~mol} / \mathrm{L}$ $\mathrm{HCl}$.

The following reference solutions were used:

- Ir (IV) dark red color solution obtained by dissolution of hexachloroiridate salt (IV);

- Ir (III) solution of light-yellow color obtained by reduction of initial synthetic solution at room temperature by ascorbic acid in 2 times excess of stoichiometry:

$2\left[\mathrm{IrCl}_{6}\right]^{2-}+\mathrm{C}_{6} \mathrm{H}_{8} \mathrm{O}_{6} \leftrightarrow \mathrm{C}_{6} \mathrm{H}_{6} \mathrm{O}_{6}+2\left[\mathrm{IrCl}_{6}\right]^{3-}+2 \mathrm{H}^{+}$. (1)

\section{Results and discussion}

Spectrograms of iridium chloride solution obtained by sintering as well as Ir (III) and Ir (IV) chloride solutions are shown in Fig. 1.

Two peaks at $\lambda=420$ and $490 \mathrm{~nm}$ are characteristic of Ir (IV) spectrum in the wavelength range under study.

Two small peaks at $\lambda=340$ and $400 \mathrm{~nm}$ are present in the spectrum of Ir (III) solution.

Calculated molar extinction coefficients for $\lambda_{1}=420 \mathrm{~nm}$ are $E_{\lambda_{1}}^{(4)}=2.310$ and $E_{\lambda_{1}}^{(3)}=81.5 \mathrm{l} /(\mathrm{mol} \cdot \mathrm{cm})$.
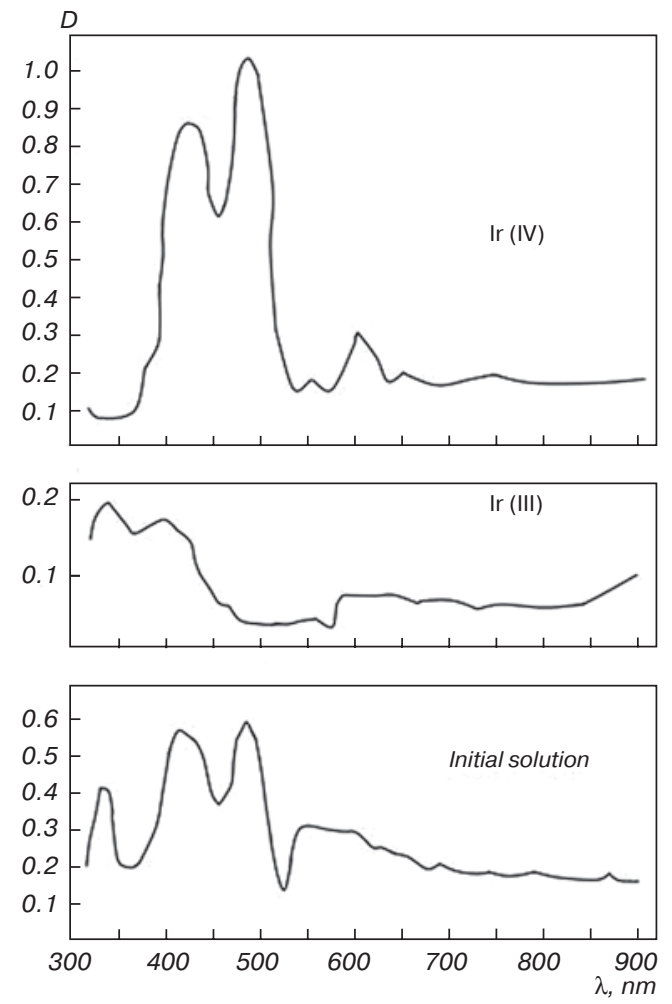

Fig. 1. Absorption spectra of iridium chloride complexes
By considering the Bouguer-Lambert-Beer law [20], the optical density of the initial solution $(D)$ at $\lambda_{1}=420 \mathrm{~nm}$ corresponds to:

$$
D_{1}=E_{\lambda_{1}}^{(3)} \cdot C_{\mathrm{Ir}^{3+}}+E_{\lambda_{1}}^{(4)} \cdot C_{\mathrm{Ir}^{4+}}=0.57 .
$$

It follows considering the total iridium concentration of $1.84 \cdot 10^{-3} \mathrm{~mol} / \mathrm{L}$ :

$$
C_{\mathrm{Ir}^{3+}}=1.65 \cdot 10^{-3} \mathrm{~mol} / \mathrm{L}, \quad C_{\mathrm{Ir}^{4+}}=0.19 \cdot 10^{-3} \mathrm{~mol} / \mathrm{L} .
$$

A similar calculation for $\lambda_{2}=490 \mathrm{~nm}$ leads to the following values:

$$
C_{\mathrm{Ir}^{3+}}=1.61 \cdot 10^{-3} \mathrm{~mol} / \mathrm{L}, C_{\mathrm{Ir}^{4+}}=0.23 \cdot 10^{-3} \mathrm{~mol} / \mathrm{L} .
$$

Based on the good agreement of the calculated data, it can be noted that in the initial solution $88.5 \%$ of iridium is in the form of hexachloroiridate (III) and $11.5 \%$ is in the form of hexachloroiridate (IV). Given that the reduction of Ir (IV) to Ir (III) in chloride solutions proceeds very easily, the peculiar character of iridium extraction from solutions is mainly determined by the behavior of Ir (III).

Cementation of iridium by zinc. The theoretical zinc consumption $\left(6 \cdot 10^{-3} \mathrm{~g}\right.$-eq/L) for iridium cementation was calculated based on the following reaction:

$$
2 \mathrm{Ir}^{3+}+3 \mathrm{Zn}^{0}=3 \mathrm{Zn}^{2+}+2 \mathrm{Ir}^{0}
$$

Obviously, the increase in acidity negatively affects the completeness of cementation, which is associated with the course of the side reaction of zinc dissolution. Thus, after the introduction of $3 \cdot 10^{-3} \mathrm{~g}-\mathrm{eq} / \mathrm{L}$ zinc the extraction at $0.19 \mathrm{~mol} / \mathrm{L} \mathrm{HCl}$ was $34 \%$, and at $1.65 \mathrm{~mol} / \mathrm{L} \mathrm{HCl}-$ only $1.5-2 \%$. To achieve high iridium extraction, higher zinc consumption is required, which exceeds its theoretical amount by 3-3.5 times (Fig. 2).

Prior introduction of sodium thiosulfate $\left(12 \cdot 10^{-3} \mathrm{~g}\right.$-eq/L) before cementation changes the iridium behavior: 25-35\% iridium precipitation occurs, depending on the initial acidity of the solution, which is related to Ir (IV) reduction to Ir (III) and iridium sulfide formation reactions (Fig. 3):

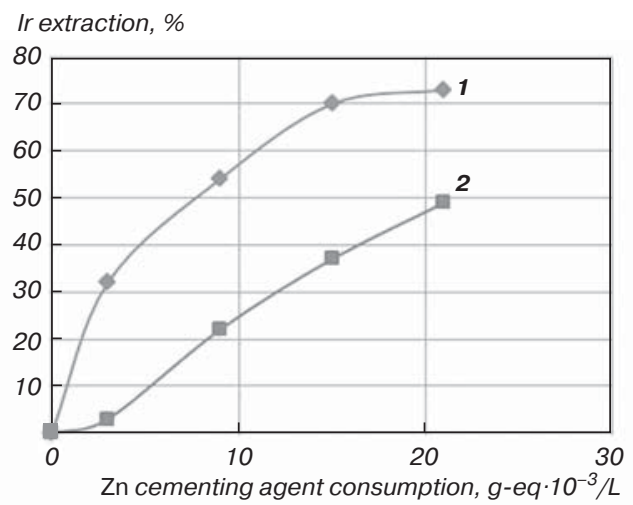

Fig. 2. Dependences of the extraction of iridium from the chloride solution vs. consumption of zinc powder and acidity of the solution, $\mathrm{mol} / \mathrm{l}$ :

$1-\mathrm{HCl}-0.19 ; 2-\mathrm{HCl}-1.65$ 


$$
\begin{aligned}
& 2\left[\mathrm{IrCl}_{6}\right]^{3-}+3 \mathrm{~S}_{2} \mathrm{O}_{3}^{2-}+6 \mathrm{H}^{+}+6 \mathrm{Cl}^{-}= \\
& =\mathrm{Ir}_{2} \mathrm{~S}_{3} \downarrow+3 \mathrm{SO}_{2} \uparrow+3 \mathrm{Cl}_{2} \uparrow+12 \mathrm{Cl}^{-}+3 \mathrm{H}_{2} \mathrm{O}
\end{aligned}
$$

When zinc is introduced, iridium precipitation (from 38 to $51 \%$ ) occurs. This is especially affected when the acidity of the solution is $0.19 \mathrm{~mol} / \mathrm{L} \mathrm{HCl}$ : without sodium thiosulfate the precipitation of iridium with the first portion of the powder was $1 \%$, then with the introduction of thiosulfate ion - more than 52\% (Fig. 3).

Cementation of iridium by iron. The theoretical iron consumption for iridium cementation was calculated based on the following reaction:

$$
2 \mathrm{Ir}^{3+}+3 \mathrm{Fe}^{0}=3 \mathrm{Fe}^{2+}+2 \mathrm{Ir}^{0} .
$$

With different acidity of solutions, with the introduction of iron powder in an amount of less than $6 \cdot 10^{-3} \mathrm{~g}-\mathrm{eq} / \mathrm{L}$, the cementation of iridium proceeds was very slow; iridium extraction was less than $5 \%$ at $6 \cdot 10^{-3} \mathrm{~g}$-eq/L of iron powder. Iridium extraction at considerable excess of iron (up to 3.5 times) and contact duration of $60 \mathrm{~min}$ at all acidity values did not exceed $30 \%$. The low cementing ability of iron in comparison with zinc (Figs. 2, 4) is consistent with the values of

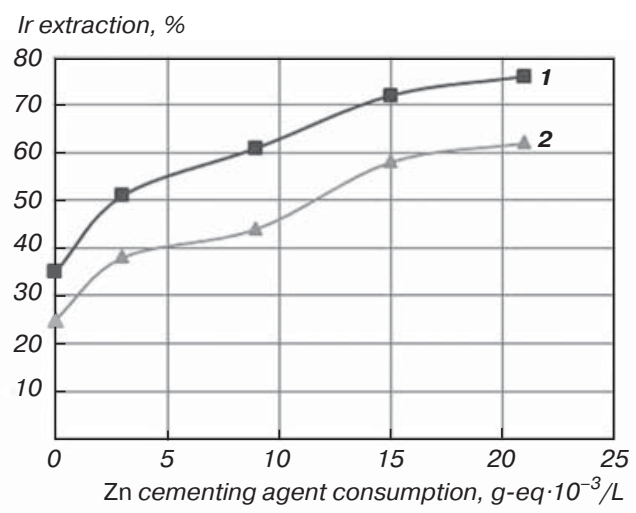

Fig. 3. Dependences of the extraction of iridium from the chloride solution vs. consumption of zinc powder and acidity of the solution in presence of sodium thiosulfate, $\mathrm{mol} / \mathrm{l}$ :

$1-\mathrm{HCl}-0.19 ; 2-\mathrm{HCl}-1.65$

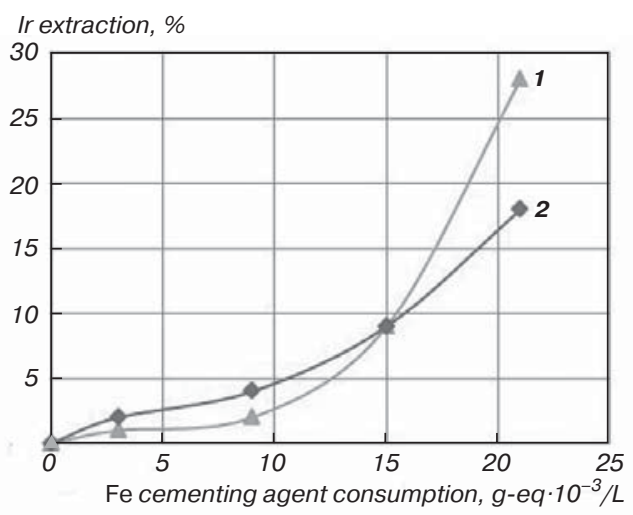

Fig. 4. Dependences of the extraction of iridium from the chloride solution vs. consumption of iron powder and acidity of the solution, $\mathrm{mol} / \mathrm{l}:$

$1-\mathrm{HCl}-0.19 ; 2-\mathrm{HCl}-1.65$ redox potentials of the corresponding systems $\left(\varphi_{\mathrm{Zn}^{2+} / \mathrm{Zn}}=\right.$ $\left.=-0.763 \mathrm{~V}, \varphi_{\mathrm{Fe}^{2+} / \mathrm{Fe}}=-0.440 \mathrm{~V}\right)$.

Pre-treatment of solutions with sodium thiosulfate significantly increases iridium extraction. At medium acidity of $0.19 \mathrm{~mol} / \mathrm{L} \mathrm{HCl}$ and at introduction of iron powder in the amount of $21 \cdot 10^{-3} \mathrm{~g}$-eq/L, extraction of iridium increases from 28 to $74 \%$, at $1.65 \mathrm{~mol} / \mathrm{L} \mathrm{HCl}$, from 18 to $52 \%$ (Figs. 4, 5). The addition of sodium thiosulfate allows obtaining better results during cementation by iron than during cementation by zinc without thiosulfate ion and similar to those obtained during cementation by zinc with prior addition of thiosulfate ion.

In order to select the optimal reducing agent, other sulfur-containing salts were tested as additives including sodium sulfide, sodium sulfite, and sodium dithionite. Cementation was performed with iron at a concentration of $0.82 \mathrm{~mol} / \mathrm{L} \mathrm{HCl}$. The test results show that sodium thiosulfate is the most effective additive, which additionally provides up to $80 \%$ of iridium extraction during its cementation by iron (Fig. 6).

Iridium precipitation by sodium thiosulfate. Changing thiosulfate consumption to $40 \mathrm{~g} / 1$ with the interaction time of 4 hours at $80^{\circ} \mathrm{C}$ provides an increase of iridium

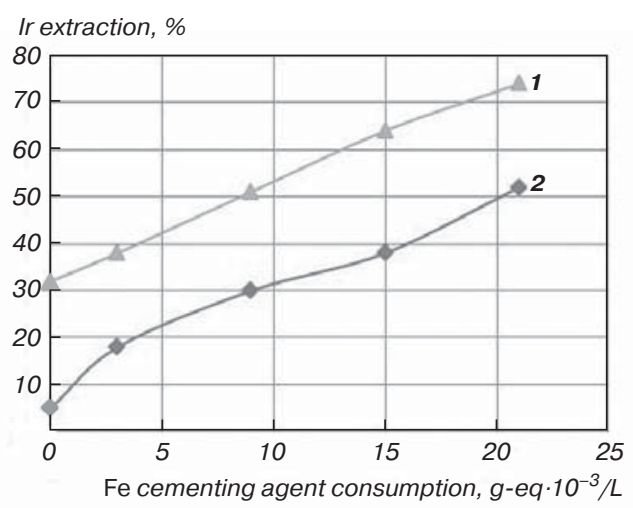

Fig. 5. Dependences of the extraction of iridium from the chloride solution vs. consumption of iron powder and acidity of the solution in presence of sodium thiosulfate, $\mathrm{mol} / \mathrm{l}$.

$1-\mathrm{HCl}-0.19 ; 2-\mathrm{HCl}-1.65$

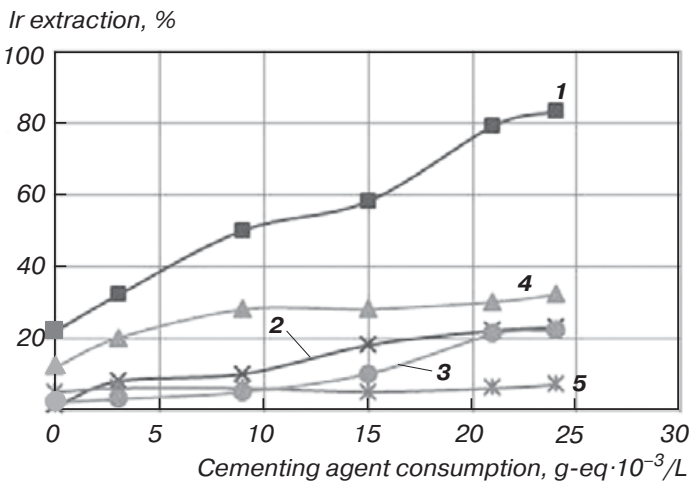

Fig. 6. Effect of sulfur-containing additives on iridium cementation by iron Reagent consumption $12 \cdot 10^{-3} \mathrm{~g}-\mathrm{eq} / \mathrm{L} ; 0.82 \mathrm{~mol} / \mathrm{L} \mathrm{HCl}$ : $1-\mathrm{Na}_{2} \mathrm{~S}_{2} \mathrm{O}_{3} ; 2-\mathrm{Na}_{2} \mathrm{~S}_{2} \mathrm{O}_{4} ; 3-$ without additives; $4-\mathrm{Na}_{2} \mathrm{~S}$; $5-\mathrm{Na}_{2} \mathrm{SO}_{3}$ 


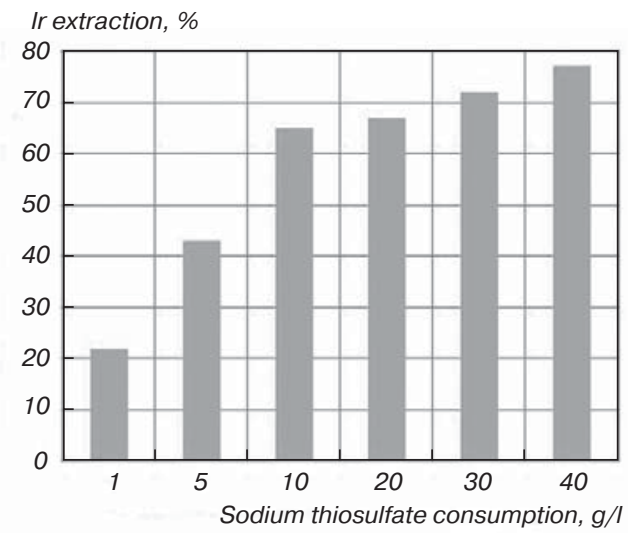

Fig. 7. Effect of sodium thiosulfate consumption on iridium precipitation

extraction into an insoluble residue up to $77 \%$ at the initial solution acidity of $0.27 \mathrm{~mol} / \mathrm{L} \mathrm{HCl}$ (Fig. 7).

During the tests, the effect of air oxidation was noted on the efficiency of iridium precipitation. Under a layer of paraffin, the iridium precipitation was $5-10 \%$ higher than without it.

By considering peculiar sodium thiosulfate behavior in acid medium, caused by the formation of elemental sulfur, it can be assumed that iridium precipitation occurs due to its interaction with sulfur released during thiosulfate ion decomposition:

$$
2 \mathrm{H}_{3} \mathrm{IrCl}_{6}+6 \mathrm{~S}=\mathrm{Ir}_{2} \mathrm{~S}_{3} \downarrow+6 \mathrm{Cl}_{2} \uparrow+3 \mathrm{H}_{2} \mathrm{~S}
$$

Any reagent that decomposes in an acidic medium with the release of sulfur, such as polysulfides, can be used instead of sodium thiosulfate. However, its use is associated with certain process-related challenges. The obtained data show that sodium thiosulfate without addition of cementing agents is able to precipitate up to $80 \%$ of iridium from neat synthetic solutions.

\section{Conclusions}

The following conclusions were drawn from the study:

1. It is shown that in chloride medium iridium is present in the form of complex hexachloroiridate ions of different oxidation degree.

2. It is established that the behavior of iridium during its reduction from synthetic chloride solution with the following ratio of its forms $\operatorname{Ir}(\mathrm{III}): \operatorname{Ir}(\mathrm{IV})=9: 1$ is determined by the low kinetic inertness of mononuclear hexachloride $\left[\mathrm{IrCl}_{6}\right]^{3-}$.

3. It was shown that the use of zinc and iron as cementing agents provides iridium extraction of 28 to $72 \%$, at a temperature of $80{ }^{\circ} \mathrm{C}$ and an acidity of $0.19 \mathrm{~mol} / \mathrm{L} \mathrm{HCl}$, that is $3-3.5$ times excess of the theoretical values.

4. Prior addition of theoretical amount sodium thiosulfate for the formation of iridium sulfide is accompanied by precipitation of $25-35 \%$ iridium depending on the initial acidity of the solution.

5. Sodium thiosulfate addition levels out the differences during cementation by zinc and iron: iridium extraction from the solution containing $0.82 \mathrm{~mol} / \mathrm{L} \mathrm{HCl}$ achieves $83.2 \%$.

6 . It is found that the use of sodium thiosulfate without cementing additives provides from 51 to $77 \%$ of iridium extraction from chloride solutions at flow rates significantly higher than theoretical $\left(5\right.$ and $40 \mathrm{~g} / \mathrm{l} \mathrm{Na}_{2} \mathrm{~S}_{2} \mathrm{O}_{3}$, respectively).

7. It was shown that the use of sulfur-containing precipitators (sodium sulfide, sodium sulfite, and sodium dithionite) as additional precipitators during cementation by iron does not provide comparable extraction rates of iridium into the cake with sodium thiosulfate.

To assess the economic efficiency of the proposed methods for the extraction of platinum-group metals from chloride solutions, it is necessary to carry out studies on an enlarged scale in relation to specific industrial facilities.

\section{References}

1. Tsemekhman L. Sh., Paretskiy V. M. Modern Processing Techniques for Copper-Nickel Sulphide Concentrates: a Review. Tsvetnye Metally. 2020. No. 1. pp. 24-32. DOI: 10.17580/tsm. 2020.01.04.

2. Konovalov G. V., Kosovtseva T. R., Sizyakov V. M. Pyrometallurgical Processing of Sulfide Polymetallic Raw Stuff in Autogeneous Forced Mode. Journal of Industrial Pollution Control. 2017. Vol. 33, Iss. 1. pp. 898-904.

3. Khainasova T. S. Factors Affecting Bacterial and Chemical Processes of Sulphide Ores Processing. Journal of Mining Institute. 2019. Vol. 235, Iss. 1. pp. 47-54.

4. Aleksandrova T. N., Nikolaeva N. V., Lvov V. V., Romashev A. O. Ore Processing Efficiency Improvements for Precious Metals Based on Process Simulations. Obogashchenie Rud. 2019. No. 2. pp. 8-13. DOI: 10.17580/or.2019.02.02.

5. Bulaev A., Melamud V., Boduen A. Two-Stage Agitation Leaching of Old Flotation Tailings. Solid State Phenomena. 2019. Vol. 298. pp. 116-120.

6. Crundwell F. K., Moats M. S., Ramachandran V., Robinson T. G., Davenport W. G. Extractive Metallurgy of Nickel, Cobalt and Platinum Group Metals. Oxford, Elsevier, 2011. $622 \mathrm{p}$.

7. Nelson L. R., Georgalli G. A., Hines K. L., Hundermark R. J. Converter Processing of Platinum Group Metals. Mineral Processing and Extractive Metallurgy: Transactions of the Institute of Mining and Metallurgy. 2019. Vol. 128, Iss. 1-2. pp. 134-159.

8. Eksteen J. J., Schalkwyk van R. F., Akdogan G. Leaching of $\mathrm{Ni}-\mathrm{Cu}-\mathrm{Fe}-\mathrm{S}$ Converter Matte at Varying Iron Endpoints; Mineralogical Changes and Behavior of Ir, Rh and Ru. Hydrometallurgy. 2013. Vol. 136. pp. 36-45.

9. Fedoseev I. V., Barkan M. Sh. Improvement of Hydrometallurgical processing of sulfide copper-nickel middlings. Tsvetnye Metally. 2016. No. 5. pp. 27-32. DOI: 10.17580/tsm. 2016.05.04.

10. Stensholt E. O., Zachariasen H., Lund J. H. Falconbridge chlorine leach process. Transactions of the Institution of Mining and Metallurgy, Section C: Mineral Processing and Extractive Metallurgy. 1986. Vol. 95. pp. 10-16. 
11. Kobayashi H., Shoji H., Asano S., Imamura M. Chlorine Leaching of Nickel and Cobalt Mixed Sulfide Using Iron Chloride Solution. Journal of the Japan Institute of Metals. 2017. Vol. 81, Iss. 5. pp. 282-287.

12. Aleksandrova T. N., O'Connor C. Processing of Platinum Group Metal Ores in Russia and South Africa: Current State and Prospects. Journal of Mining Institute. 2020. Vol. 244. pp. 462- 473.

13. Mrozik M., Muiller U., Heide G., Talovina I. V., Duryagina A. M. Mineralogical Composition of Nickelhydrosilicate Ores at the Elov Deposit (The Northern Central Urals). InnovationBased Development of the Mineral Resources Sector: Proceedings Of The XI ${ }^{\text {th }}$ Russian-German Raw Materials Conference, Potsdam, Germany, 7-8 November 2018. pp. 103-114.

14. Naftal' M. N., Kuznetsov N. S., Naboichenko S. S., Solntsev K. A. Development of the Nickel-Refining Production at Norilsk Nickel Harjavalta Oy in GMK Norilsk Nickel. Russian Metallurgy (Metally). 2019. Iss. 5. pp. 495-506.

15. Livingstone S. E. The Chemistry of Ruthenium, Rhodium, Palladium, Osmium, Iridium and Platinum. Oxford, Pergamon Press. 1975. 208 p.
16. Le M. N., Lee M. S. Separation of Iridium(IV) and Rhodium(III) from Hydrochloric Acid Solution by Solvent Extraction with Cyanex 921. Geosystem Engineering. 2018. Vol. 21, Iss. 4. pp. 210-216.

17. Nikoloski A. N., Ang K. L., Li D. Recovery of Platinum and Rhodium from Acidic Chloride Leach Solution Using Ion Exchange Resins. Hydrometallurgy. 2015. Vol. 152. pp. 20-32.

18. Cheremisina O., Sergeev V., Ponomareva M., Ilina A., Fedorov A. Kinetics Study of Solvent and Solid-Phase Extraction of Rare Earth Metals with Di-2-Ethylhexylphosphoric Acid. Metals. 2020. Vol. 10, Iss. 5. pp. 1-15.

19. Nguyen T. H., Sonu C. H., Lee M. S. Separation of Pt(IV), Pd(II), Rh(III) and Ir(IV) from Concentrated Hydrochloric Acid Solutions by Solvent Extraction. Hydrometallurgy. 2016. Vol. 164. pp. 71-77.

20. Bulatov M. I., Kalinkin I. P. Practical Manual of Photocolorymetric and Spectrophotometric Methods Analysis. $4^{\text {th }}$ ed., rev. and exp. Leningrad: Chemistry, 1976. 376 p. 